\title{
25 Research Soure \\ Land Use change and its Drivers in the Wetlands of Barotse Floodplain of Zambezi River Sub-Basin, Zambia
}

Arnold Mahonko Banda ( $\sim$ bandamahonko@gmail.com )

University of Zambia https://orcid.org/0000-0003-4073-0385

Kawawa Banda

University of Zambia

\section{Enock Sakala}

University of Zambia

Machaya Chomba

Worldwide Fund for Nature (WWF) Zambia

Imasiku Anayawa Nyambe

University of Zambia

\section{Research Article}

Keywords: Barotse flood plain, drivers of land use change, land use change, wetlands, ecosystem, Zambezi River Sub Basin

Posted Date: May 27th, 2021

DOl: https://doi.org/10.21203/rs.3.rs-501786/v1

License: @ (i) This work is licensed under a Creative Commons Attribution 4.0 International License. Read Full License 


\section{Abstract}

River floodplains such as the Barotse Flood Plain (BFP) in Western Zambia, provide a large number of ecosystem services and economic value for the inhabitants. Yet, in spite of its importance, the flood plain has been vulnerable to drivers of land use change suggestive of potential wetland degradation. This study aimed at determining the extent of land use change in the wetland of BFP in the selected years between 1980 to 2020 and identifying, and assessing drivers of land use change in the wetlands of BFP using satellite data. The study utilized both secondary and primary data sources. Primary data was collected using interview schedule, key informants' interviews, Participatory Rural Appraisal and field observations. The Raosoft random sample calculator was used to determine the sample size of heads of households from 9 districts that are found within the Barotse Flood Plain. Then, proportional sample size per district out of 270 was calculated. It was found that there is land use change in the wetlands of BFP caused by many driving factors such as biophysical, economic, infrastructure development, technological, demographic, agriculture and others. The study recommended strategies such as the Government of Zambia, traditional leaders and other stakeholder should embark on protection and conservation of BFP. In addition, new policies on land use and water resources management in the wetlands such regularly monitoring of all activities taking place in and around the wetland of BFP by Water Resources Management Authority should be explored.

\subsection{Introduction}

Land use change is defined as a change from one specific use to another, rather than intensification within similar system (Journeaux et al., 2017; Zondag and Borsboon, 2009). On the other hand, wetlands are areas of marsh, fen, peat land or water, whether natural or artificial, permanent or temporary (Ramsar Convention, 1971).

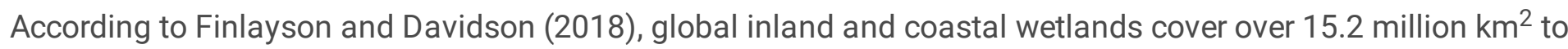
16.2 million $\mathrm{km}^{2}$ with $54 \%$ permanently inundated and $46 \%$ seasonally inundated. Wetlands cover 5-10 percent of Earth's terrestrial surface (Mitch an Gosselink, 2007). Bhatta et al., (2016) states that transitional ecosystems between terrestrial and aquatic are essential both to the health aquatic and terrestrial life forms (Keddy et al., 2009; Cohen-Shacham, 2005), as they support high biodiversity and human society livelihoods ((Mitch an Gosselink, 2007). Bhatta et al., (2016) further states that as hydrological functions, wetlands control floods by slowing down water movement, reducing water velocity and sedimentation (Keddy, 2000) and promote aquifer replenishment (Gosselink and Turner, 1978). These wetlands are endowed with numerous ecosystem services that are of economic value as they support millions of people and are habitats for number of biota (USAID, 2004; Hagos et al., 2014) although currently they are experiencing unprecedented and extensive environmental degradation and damage due to land use change. Almost $71 \%$ of wetlands disappeared during the twentieth century (Gardner et al., 2015). Inland or terrestrial wetlands depleted at higher rate as compared with coastal wetlands (Davidson, 2014). FAO (2008), further argues that these changes to wetlands are likely to be most severe in the developing countries like Zambia, with rapidly developing economies and growing population due to intensified food production often in previous marginal or little used areas. Therefore, wetlands require immediate and sustained conservation attention as they are experiencing decline (MEA, 2005).

Land use change in the wetlands is as a result of socio-ecological processes on a landscape driven by complex forces. Socio-ecological systems are defined as an ecological system complex linked with and affected by one or more social system (Redman et al., 2004). The ecological system comprises of geologic setting, climate and its variability, pattern of primary productivity, hydrological processes, and others geophysical factors (Geist at al., 
2002). The social system acts synergistically rather than by single-factor causation, with more than one-third of the cases being driven by the full interplay of economic, policy and institutional framework, technological, cultural, and demographic factors (Msofe, 2019; Redman et al., 2004; Journeaux et al., 2017; Zondag and Borsboon, 2009). These drivers of land use change tend to interact and influence each other. Global mega-trends are also important, including demography, globalization, consumption and urbanization, with climate change creating uncertainty at every level (Ramsar, 2018).

Biophysical factors include soil type and its characteristics. Soil type and its characteristics can influence the utilization of a given landscape where some utilization may be unsustainable hence leading to land use change (Jouarneaux et al., 2017). Topography, particularly slope can lead to land use change especially where no conservation is practiced (Velldamp and Lambin, 2000; Jouarneaux et al., 2017). Therefore, hydrological conditions can support certain types of land use (ecological systems), and the downstream can be protected by upstream regulations.

The other biophysical driving force of land use change is climate change or climate variability which influence land use in multiple ways such as via periods of intensified rainfall or drought, seepage of saltwater, demand for storage water, changing temperatures and humidity affecting the condition of biotopes, or agricultural production (Redman et al., 2004; Zondag and Borsboon, 2009). Climate change/variability is recognized as a major threat to the survival of species and integrity of ecosystem worldwide (Hulme, 2005) in the wetlands. Climate change is a direct and indirect driver of land use change. According to Phiri et al., (2013), the impacts of climate change are evidenced through gradual increase in average temperatures averaging $0.3^{0} \mathrm{C}$ per decade and declining trend in amount of rainfall. Rainfall trend has declined to $-10 \%$ in Zambia in the last decades (IPCC, 2001). Phiri et al., (2013), further states that an increasing temperature and reducing precipitation scenario along with other environmental factors, contribute to increased evapotranspiration which leads to drying up of wetlands with adverse effects in food security for the poor rural people. Intensified rainfall and drought have an important impact on the amount of land use for water and water quality. Shand et al., (2017) argue that climate variability is a key driver of dewatering in wetland systems. Superimposed on this are the effects of climate change or variability in terms of amount, timing and distribution of rainfall and discharge, and that, these do not work in isolation (Shand et al., 2017). Despite this, there remains a lack of integration of land use change and climate change and variability in studies of wetlands (Piggot et al., 2015; Tinawaki et al., 2017). This therefore, calls for immediate understanding of the interaction effects of climate variability and land use change in the wetlands as necessary to inform climate change adaptation and mitigation measures (Mantyaka et al., 2019). However, climate change policies such as mitigation or adaptation strategies can also lead to land use change in the wetlands if not properly implemented (Zondag and Borsboon, 2009) for example, infrastructural development like dredging of canals that may drain water from the wetland hence leading to drying up of wetlands. This means that adaptation and mitigation measures can have multiplier effects in addressing other drivers of wetland change if not properly implemented.

The other driving force of land use change is economic factor which can impact land use through relative profitability of the land use, access to capital or credit, infrastructure, market, access to information, subsidies access to skilled labour and land tenure. These can impact land use depending on how they are employed for economic benefits (Redman et al., 2004; Jouarneaux et al., 2017; Lambin et al., 2003). Economic developments also affect land use in terms of growth in income and trust funds, rise in double-income households, changes in economic structure, agglomeration forces, global and local market development and organization of production 
process (Redman et al., 2004; Zondag and Borsboon, 2009; Msofe, 2019). The high output market prices for agricultural products for example, compel farmers to increase productivity through allocation of more resources such as labour, fertilizers and agro-chemicals on limited land to maximize output hence agricultural intensification (Msofe, 2019; Müller, 2004). The release of agricultural land (marginal or not) has been matched by socio-economic and policy context with unprecedented urbanization leading to the loss of ecological functions of land and soil (Ramsar, 2018). The economic driver also stimulates other infrastructure developments such as construction of roads, bridges and canals in the wetlands which leads to potential floods damage.

Technology developments are an important driving force behind developments in many sectors and the organization of society as a whole, which often results in land use changes. This has been a dominant driver behind changes in agriculture which consequently affect land use. Technology developments have resulted in higher levels of productivity in terms of land devlopment and therefore, it is possible to increase agricultural production while agricultural land areas are diminishing leading to encroachment of marginal wetlands (Msofe, 2019; Zondag and Borsboon, 2009). Technology developments which increase productivity in agriculture technological options also affect underground water storage or desalination of water henceforth affecting land use in the wetlands (Zondag and Borsboon, 2009). This is done through agriculture intensification that involves the access to high yield-increasing technologies such as the use fertilizers, pesticides and improved seeds that opportunities to increase agricultural production (Msofe, 2019; Müller, (2004) and this affects the health of wetlands. Agricultural expansion involves massive clearance of the land for agriculture and is assisted with the use of technologically advanced machines such as tractors and power tillers (Geist and Lambin, 2002). There are also some various government policies that affect land use such as scale policies that are at international, national or local levels. The sector level policies that influence spatial planning also can lead to land use change, which in turn affects wetlands and ecosystem (Zondag and Borsboon, 2009).

Demography as driving force of land use change in wetlands consists of different components which affect size and composition of population and households. Demographic developments are influential because the behaviour of actors often is related to demographic characteristic (Zondag and Borsboon, 2009). For example, birth rate, life expectancy, household formation and dissolution, and migration exert pressure on natural resources which lead to unsustainable utilization of wetland resources (Zondag and Borsboon, 2009). Population increases entails increased demand for food supply and improved income which has resulted to over exploitation of wetlands resources and inappropriate agricultural practices that has led to wetland conversion and degradation (Nguyen et al., 2017). Concurrently, conflict and unclear land tenure coupled with a desire for higher income, incentive in commodity prices have driven the community to transform from traditional to extensive cropping system and expansion of cultivated land into the protected wetlands ((Nguyen et al., 2017). Land use change by humans from last few decades is one of primary factors responsible for wetland degradation (Alam et al., 2011). Ramsar (2015), further states that human activities taking place around and within the wetland area are the most driving force for wetland degradation globally. Related to demographic factor is societal values and trends that have important impact on almost any of land use (Alam et al., 2011). For example, changes in people's lifestyle can directly affect infrastructure development types in the margins of wetlands. According to Ruben et al., (2008), population growth, consumer tastes, international trade, and other factors can affect the demand for land in different uses and location of economic production. Alam et al., (2011), in their study on the "impact of land use/land cover dynamics on Himalayan wetland ecosystem, found out that land use change over time, based on human needs has modified the physical environment in the area. That, the growing population 
has significantly altered the natural landscape. The study further revealed that there has been loss in natural vegetation, agricultural lands, water bodies and open space particularly due to increasing residential and commercial land uses. The conversion of land from one use to other has put a wide range of negative effects as far as overall health of the watershed is concerned (Alam et al., 2011).

Due to the above drivers of land use, wetlands continue to be lost and degraded through drainage and conversion, introduction of pollution and invasive species, extraction activities, and other actions affecting ecosystem services, water quantity and quality, and frequency of flooding and drying (Alam et al., 2011). Some scholars have used some models like econometric analyses of land use model in the wetlands to examine the relationship between observed land-use patterns and measures put to address changes, Patuxent Landscape Model (PLM) that aim at simulating the functioning of the land use system and the spatially explicit simulation of near future land use patterns, Empirical-Statistical model or Simulation model (CLUE and CLUE-S model) and other models. However, there has been limited studies on the relative importance of the above highlighted drivers of land use change in driving land use changes in the wetlands. Models such as Integrated/Hybrid model or Optimization model (IIASA-LUC model) is useful for disentangling the complex suite of socio-economic and biophysical forces that influence the rate and spatial pattern of land use change and for estimating the impacts of changes in land use (Verburg et al., 2004). Furthermore, this model can support the exploration of future land use changes under different scenario conditions (Verburg et al., 2004). While such models enable simulations of policy changes accounting for both changes in land use and corresponding effects, Empirical-Statistical model or Simulation model (CLUE and CLUE-S model), Patuxent Landscape Model PLM and others are limited in their ability to measure the impacts of different factors on land use change historically (Verburg et al., 2004). To the best of our knoAFGedge, no study has been done to assess the drivers of land use change in the Barotse Wetlands of Western Zambia in order to influence meaningful policy changes and conserve the wetlands. This study aims to assess land use change and its drivers in the wetlands of Barotse Floodplain and it adopted Integrated/Hybrid model or Optimization model (IIASA-LUC model). This paper therefore, measures the relationship between drivers of land use change and observed land use changes pattern in the wetlands of Barotse Flood Plain.

\subsection{Materials And Methods 2.1 STUDY AREA}

Figure I: Map showing Barotse Floodplain in Western Province, Zambia (Adapted from Zimba, 2017)

Barotse Flood plain is one of the wetlands in the Southern Africa which has been experiencing a change from unsustainable wetlands utilization (source). Many communities in Barotse Flood plain in the Zambezi River Subbasin of Western Province depend on this wetland for their livelihoods but there are emanating threats to this wetland. Barotse Flood plain was selected as the study area due to its importance to the ecosystem services it provides and a source of livelihoods to the local people in Western Province and Zambia at large. The flood plain is an extensive area of comparatively level to gentle undulating land, lacking surface irregularities, and usually adjacent to a higher area (source). Its elevation ranges from 1192m above sea level in the northern eastern part, at Mitete and Lukulu to $900 \mathrm{~m}$ above sea level, at Senanga and Sioma. Its coordinates are $15^{\circ} 40^{\prime} 0^{\prime \prime} \mathrm{S}$ and $23^{\circ} 10^{\prime} 0^{\prime \prime}$ E in DMS (degrees Minutes and Seconds) or -15.6667 and 23.1667 (in decimal degrees Its geographical location is between $13-17^{\circ}$ South and $22-24^{\circ}$ East of western Zambia in Southern Africa. Barotse Floodplains averages 30 
$\mathrm{km}$ width along most of its length and is about $50 \mathrm{~km}$ at widest north of Mongu Town, the headquarters of Western Province. Estimate area coverage is $5500 \mathrm{~km}^{2}$ (1.2 million hectares) though maximum flooded area is approximate at $10,750 \mathrm{~km}^{2}$ when floodplain of the several tributaries such as Luena flats are taken into account (Timberlake, 1997; IUCN, 2003). It is drained by Zambezi River, Luanginga River, Lungwebungu River and Kabompo River as major rivers.

The area experiences three seasons namely: cold dry season (May to August), hot dry season (September to October) and hot wet season (November to April). Temperature varies from mean maximum of $30^{\circ} \mathrm{C}$ and mean minimum of $20^{\circ} \mathrm{C}$. The area has the greatest temperature extremes with hot maximum of about $40^{\circ} \mathrm{C}$ and freezing in dry cold season to about $4^{\circ} \mathrm{C}$. It receives less than $800 \mathrm{~mm}$ of rainfall annually (source). Western province has Barotse sand type of soil. The Kalahari sands are underlined by rocks of the Karoo Supergroup. The sands are a Pleistocene deposit, the erosion product of the weak Upper Karoo sandstones. They vary in colour from pallid to orange, are moderately acidic and contain 3 to 12 percent silt plus clay. The sands are not very fertile; the nitrogen content is particularly low where the humus has been disturbed by cultivation. Annual floods deposit are essential nutrients to otherwise nutrient deficient Kalahari sand soil (Aregheore 2009). There is no erosion problem as the area is so flat, but heavy population pressure in some areas has resulted in land degradation (Fanshawe, 2010).

The Kalahari sands favour growth of vegetation which is of great value to local people both domestic and commercial uses. The area is predominantly grassland with breaks of semi-evergreen forest, evergreen forest, deciduous forest and shrub land. Other land cover types include mosaic cropland, water bodies and regularly flooded vegetation which covers the Barotse Flood Plain. The evergreen and semi-evergreen forest is composed of swamp and riparian woodlands while the deciduous forest is of Kalahari and Munga Woodland. The major land uses are cropland, cattle grazing and timber production (Fanshawe, 2010; Mukosha, 2014). There are a variety of underground trees some of which are confined to the wetland. They have a dwarf habit with the main woody stem underground. The underground growth nature is attributed to adaptation to the high-water table and anaerobic conditions on seasonally-flooded plains. The above ground shoots are often destroyed by fire or frost. The trees spread by means of rhizomes (Timberlake, 2000).

The major economic activities of the study area are small-scale trade such as sale of fish, cattle, agricultural produce, aquatic plants, and forestry products. The source of income for the local people is limited due to a lack of modern industries apart from timber industry. Therefore, the income levels of the people in the area are equally low $(C S O, 2012)$. However, the area has great potential for tourism development because of its strategic location, floodplains, existing biodiversity and local people's willingness to conservation. The area holds a cultural ceremony called "Kuomboka," an annual event which attracts tourists from all over the world and from the nearby villages and towns (Flint 2006).

\subsection{DATA COLLECTION}

The research adapted Integrated/Hybrid or Optimization model or approach to ensure that all the required data was collected using combined methods to adequately answer research objectives (Fig. 2)

\subsubsection{Sources of data}


The study utilized both secondary and primary data sources. Secondary data was obtained mainly from archival sources (published and unpublished). Extensive review of existing literature; both published and unpublished, on land use change and its drivers was conducted. The source of land use/ landcover information was from Landsat imagery based on the work of Zimba, 2017. Primary information on drivers of land use change, local knowledge on drivers of land use change was collected using interview schedule, key informants' interviews, Participatory rural appraisal and field observations. The data was collected from Lukulu, Mitete, Mongu, Nalolo, Kalobo, Sikongo, Senanga, Limulunga and Sioma Districts. These are the districts that are within and around Barotse Flood plain.

\subsubsection{Interview schedule}

The interview schedule was administered on 270 heads of households that were randomly and proportionally selected from 9 districts that are found within margins of Barotse Floodplain. In Sect. 2.2.6, a description of the sampling approach is provided. The information which was collected using interview schedule included: history of Barotse Flood plain and the people in their present location, divers of land use change, and status of wetland of Barotse Flood Plain and its resources.

\subsubsection{Key informant interviews}

Representatives of the government authorities, including district commissioners, agricultural officials, fisheries officials, house of chiefs officials and traditional leadership, WARMA officials, ZMD officials, NGOs, and others were interviewed. Interviews were held to understand deeper the history of Barotse Flood plain, drivers of land use change and status of flood plain. The key questions asked during interviews focused on drivers of land use change, status of floodplain and history of Barotse Flood plain. Criteria for selection of the key informants were their wetland about the Barotse Floodplain and its resources and their key role in the management of the flood plain.

\subsubsection{Participatory rural appraisal (PRA)}

PRA is a tool which is used in a lot of different situations to achieve very different research objectives. It involves collecting information by talking directly to a group of people on the ground guided by laid down guidelines on how to approach the collection of information, learning from that information and the involvement of local people in its interpretation and presentation. It involves stimulating interaction with community members and local community members take a lead in discussion and identifying issues and suggesting solutions by presenting their knowledge, concerns and priorities to a researcher. PRA was used to identify land use changes and the driving forces of land use change in the wetlands of Barotse flood plain from different views of participants through group discussions. PRA method was also used for preliminary understanding of the overall land use change in this study site. Using this method, local communities in groups were able to identify affected sites in the flood plain and documented them on flip charts. Therefore, local people came up with the resource maps in their respective areas indicating available resources, affected landscapes, infrastructures developed such as roads, bridges, canals, schools, lodges, etc. This was done in all the 9 districts.

\subsubsection{Field observation}

Field observation were conducted by the way of capturing photos using a digital camera and taking notes of observed landscapes and other features in the transects. Photographs of the areas of interests showing different land practices were taken. Major land use activities that were being practiced in the area were also identified and 
captured. Condition of the floodplain in the area was also observed. A GPS was used to record ground control points. This data was important for validation.

\subsubsection{Sampling Procedure}

Simple random sampling was used in order to avoid bias in the result and ensure that initial selection of respondents had the same probability of being selected. The Raosoft random sample calculator (www.raosoft.com) was used to determine the sample size of heads of households from 9 districts that are found within the Barotse Floodplain. The margin of error was $5 \%$ at confidence level of $90 \%$ and $50 \%$ respondents' distribution. Since the total number of households was 104,097 (CSO, 2012), therefore sample size calculated was 270 . Then, proportional sample size per district out of 270 was calculated (see Table 1). All the names of the heads of various households in the sampled villages was extracted from the registers that are regularly updated and kept at the District Administration Offices from 9 district. The sample of 270 was a reasonable sample size whose results can be inferred onto the whole population of the Barotse Flood plain because it is above 30 , the rule of thumb. The calculation of the sample was based on the normal distribution. To determine the number of heads of households to be interviewed per district, proportional calculation was done and the proportional sample figures are shown on Table 1.

Table 1

showing the calculated proportional sample size per district out of 270 total calculated sample size by Raosoft random sample calculator in BFP.

\begin{tabular}{|llll|}
\hline S/N & DISTRICT & $\begin{array}{l}\text { NUMBER OF HOUSEHOLDS PER } \\
\text { DISTRICT }\end{array}$ & $\begin{array}{l}\text { CALCULATED PRORPORTIONAL SAMPLE PER } \\
\text { DISTRICT }\end{array}$ \\
\hline 1 & LUKULU & 11230 & 29 \\
\hline 2 & MITETE & 5446 & 14 \\
\hline 3 & SIKONGO & 9538 & 25 \\
\hline 4 & KALOBO & 16942 & 44 \\
\hline 5 & NALOLO & 10841 & 28 \\
\hline 6 & SENANGA & 14321 & 37 \\
\hline 7 & SIOMA & 7189 & 19 \\
\hline 8 & LIMULUNGA & 10180 & 26 \\
\hline 9 & MONGU & 18410 & 48 \\
\hline TOTAL & 104097 & 270 \\
\hline
\end{tabular}

\subsubsection{Data Analysis}

\subsubsection{1 imagery data analysis}

Imagery data analysis was done using the approach in Fig. 3 below.

Landsat 5 TM and Landsat 8 OLI-TIRS (Operational Land Imager Thermal Infrared Sensor) imagery were accessed from NASA (National Aeronautics and Space Administration) via the internet portal glovis 
(http:/glovis.usg.gov). The shape file covering the study area was used to cut out and download images. Landsat data were downloaded from scenes at paths 174 to 176 with rows at 070 to 071 . Land use change detection and analysis were performed based on imagery for the years 1984,1986,2004 and 2015. Land cover classification was used to detect land use change (increased or decreased). Land use changes classes were generated from land cover maps for each year. Classification was performed in ENVI 5.1 using Maximum Likelihood Classification Algorithm. Classification was based on training areas for each year and classes were: grassland/shrubland/bare, water, annual flooded grassland, grassland and forested/woody/vegetated. For easy of extraction of statistic for analysis classes with similar parameters such as forest types and grasslands were merged to form compound classes such as forest land and grassland.

The accuracy assessment was done using the ground-truth with region of interests (ROl's) tool in the post classification module in ENVI 5. Accuracy assessment of the land cover classification was done using the confusion matrix. The confusion matrix was generated based on ground truthing data (extract from Zimba, 2017).

\subsubsection{Quantitative data analysis}

Quantitative data was analyzed using Statistical Package for the Social Sciences (SPSS). Descriptive statistics comprising of frequencies and percentages were used to describe the field data. Graphical representations of these data were made where necessary, using tables and graphs. Pearson correlation coefficient was used to measure the degree of association between drivers of land use change and observed land use change pattern.

\subsubsection{Qualitative data analysis}

Hyper research tool was used to analyze patterns and trends among qualitative data collected from key informants and PRA. Data was summarized through the process of data reduction. This involved coding themes according to the research questions and by categorizing similar coded themes groups together.

\subsection{Presentation Of Results And Discussion}

\subsection{Detected Extent of Land Use Change in BFP}

The interpretation of the mapping results of wetland condition (WC) starts with details of land cover (LC), and the land use change (LUC) detected from land cover change (LCC) between the years under review. The above details provide a basis for determining the current status of the wetland in Barotse Flood Plain. For instance, based on the image data of 1984, 1996, 2004 and 2015 processed for BFP the LU total change rate was estimated at 1.59 percent while the annual average rate of change was estimated at 0.05 percent. The change per class was that forested/woody and vegetated (FWV) had the annual change rate of 0.31 between 1984-1996 to 0.51 between 1996-2004 and later changed to 0.18 between 2004-2015. Grassland (GL) annual change rate between 19841996 was 0.65 and changed to 0.99 between 1996-2004. Between 2004-2015 it further the changed to 0.19 percent. In the class of annual flooded grassland (AFG) annual change rate was 0.46 between 1984-1996 to 0.08 between 1996-2004 and later to 0.14 between 2004-2015. Water (WT) class has the greatest change. Between 1984-1996 the annual change rate was at 0.01 and changed to 0.35 between 1996-2004 and drastically changed to -0.2 between 2004-2015. For the class of Grassland/Shrubland/Bare land (GSB), between 1984 and 1996 the change was 0.79 to 1.22 between 1996-2004 and later to 0.73 in the period 2004-2015 (see Table 2). The greatest change was in the class of water followed by wetland. The land use change detected in 
BFP is similar to that of Banda (2017) and Banda et al., (2013) that detected forest land cover change in Masese Local Forest (MLFR) in Sesheke District of Western Province, Zambia. It can therefore, be generalized that the natural resources stock has been affected by various factors in Western Province and Zambia at large.

According to maps (Fig. 4) and land cover statistic (Table 4), for AFG there was an increase in area cover percentage of 5.25 percent between 1984 and 1996 and later started decreasing. For instance, in the period between 1996 and 2004 it decreased to 0.63 percent. It later increased slightly between and 2004 and 2015 to 1.53 percent. In general, there has been continuous decrease of AFG in cover in BFP since 1996. The overall change in the class of AFG between 1984 to 2015 was 3.36 percent with an annual rate of decrease of 0.11 percent (Table 4). For GL class in the period 1984-1996 grassland land cover class increased by 7.8 percent and further increased to 7.89 percent in the period 1996-2004 and later decreased drastically to 2.29 percent in the period 2004-2015. The WT class reduced to 0.12 percent in the period 1984-1986 and later increased to 2.81 percent between 1996 and 2004 and drastically reduced to -2.2 percent between 2004 and 2015. The FWV class changed to 3.6 in percentage between 1984 and 1996 to 4.0 in the period 1996-2004 and further changed to 2.0 between 2004 and 2015.

Table 2

Land use change in percentage of land use classes over the assessed years and periods in BFP.

\begin{tabular}{|c|c|c|c|c|c|c|c|c|c|c|c|c|}
\hline \multirow[b]{2}{*}{ CLASS } & \multirow{2}{*}{$\begin{array}{l}1984 \\
\underset{\%}{\text { LUC }} \\
\end{array}$} & \multirow{2}{*}{$\begin{array}{l}1996 \\
\text { LUC } \\
\%\end{array}$} & \multicolumn{2}{|c|}{ 1984-1996 } & \multirow{2}{*}{$\begin{array}{l}2004 \\
\begin{array}{l}\text { LUC } \\
\%\end{array}\end{array}$} & \multicolumn{2}{|c|}{ 1996-2004 } & \multirow{2}{*}{$\begin{array}{l}2015 \\
\begin{array}{l}\text { LUC } \\
\%\end{array}\end{array}$} & \multicolumn{2}{|c|}{ 2004-2015 } & \multicolumn{2}{|c|}{ 1984-2015 } \\
\hline & & & PC & ARC & & $P C$ & ARC & & PC & ARC & PC & ARC \\
\hline FWV & 55.14 & 51.46 & 3.68 & 0.31 & 47.39 & 4.07 & 0.51 & 45.37 & 2.02 & 0.18 & 9.77 & 0.32 \\
\hline \multicolumn{13}{|l|}{ FWV } \\
\hline GL & 21.16 & 28.96 & 7.8 & 0.65 & 21.07 & 7.89 & 0.99 & 18.78 & 2.29 & 0.19 & 2.38 & 0.07 \\
\hline AFG & 9.92 & 15.44 & 5.52 & 0.46 & 14.81 & 0.63 & 0.08 & 13.28 & 1.53 & 0.14 & 3.36 & 0.11 \\
\hline \multicolumn{13}{|l|}{ AFG } \\
\hline WT & 0.67 & 0.55 & 0.12 & 0.01 & 3.36 & 2.81 & 0.35 & 1.16 & -2.2 & -0.2 & 0.49 & 0.02 \\
\hline \multicolumn{13}{|l|}{ WT } \\
\hline GSB & 13.11 & 3.59 & 9.53 & 0.79 & 13.36 & 9.77 & 1.22 & 21.42 & 8.06 & 0.73 & 8.3 & 0.26 \\
\hline \multicolumn{13}{|c|}{$P C=$ Percentage Change,$A R C=$ Annual Rate of Change FWV = Forest $/$ woody vegetation, } \\
\hline & 1 & D & , & & IT & 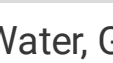 & D. & 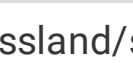 & 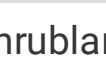 & & & \\
\hline
\end{tabular}

Table 2 show that there have been LUC in penetrance since 1984 to 2015 . The Table also shows that the delineated land cover area classes in the catchment area have been reducing apart from Grassland/shrubland/bare land that has been increasing in areal coverage. Grassland/shrubland/bare land delineated land cover area only reduced in the period 1984 and 1996 (3.59 percent) and between 1996-2004 it 
increased to 13.36 percent, and further increased to 21.42 percent between 2004-2015, as a result of wetland and water classes delineated land cover areas that decreased in the same period.

Figure 5 shows that there was a general decrease in land cove in percentages in all classes apart from GSB delineated land cover area. In the study area the wetland is composed of water, annual flooded grassland, grassland, and shrubs. In general, the extent of wetland has declined in BFP.

The decrease in wetland land cover is as a result of conversion of wetland to crop fields (rice and maize), overgrazing as a result of overpopulation of domestic livestock and infrastructure development and others (Plate 1).

\section{Plate 1: Photo showing bare land patches in BFP}

The studies done by Timberlake $(1998,2000)$ and Fanshawe (2010) also indicates the loss in biodiversity in and around the Wetland of Barotse Flood Plain. They attributed these losses to a host of anthropogenic induced factors which included: (i) the increased pressure for agricultural land expansion; (ii) settlements; (iii) timber production; (iv) energy; (v) increased population of livestock and (iv) harvesting of wetland resources for other livelihood purposes. Therefore, infrastructure development, expanded rice fields and other crops fields and overgrazing due to ever increasing population of cattle are some of the causes of land use changes in Barotse Flood Plain.

\subsection{Divers of land use change in BFP}

The data was collected using the interview schedule, key informants interview, PRP and observations. The findings on the drivers of land use change in the BFP indicate that climate variability (48.5\%) is a leading driver of land use change. The second driver of land use change in this flood plain is Infrastructure development (roads and bridges) (20.7\%) followed by demographic factors (18.5\%). Agriculture is the least in causing land use change in BFP. Only $4.4 \%$ of respondents alluded to agriculture as a driving force of land use change in the area. Table 2 shows the results in terms of frequency, percentage and how the results deviate from the mean. 
Table 3

showing the responses on driving forces of land use change and observed land use changes pattern in the Barotse floodplain

\begin{tabular}{|c|c|c|c|c|c|c|c|c|}
\hline & & Frequency & Percent & $\begin{array}{l}\text { Valid } \\
\text { Percent }\end{array}$ & $\begin{array}{l}\text { Cumulative } \\
\text { Percent }\end{array}$ & $\begin{array}{l}\% \\
\text { Mean }\end{array}$ & $\begin{array}{l}\text { Std. } \\
\text { Deviation }\end{array}$ & $\mathbf{N}$ \\
\hline \multirow{5}{*}{$\begin{array}{l}\text { Driving } \\
\text { forces of } \\
\text { land use } \\
\text { change in } \\
\text { Barotse } \\
\text { Flood plain }\end{array}$} & $\begin{array}{l}\text { Climate } \\
\text { variability }\end{array}$ & 131 & 48.5 & 48.5 & 48.5 & \multirow[t]{5}{*}{2.30} & \multirow[t]{5}{*}{1.589} & \multirow[t]{5}{*}{270} \\
\hline & Demographic & 50 & 18.5 & 18.5 & 67.0 & & & \\
\hline & Technology & 21 & 7.8 & 7.8 & 74.8 & & & \\
\hline & Agriculture & 12 & 4.4 & 4.4 & 79.3 & & & \\
\hline & $\begin{array}{l}\text { Infrastructure } \\
\text { development }\end{array}$ & 56 & 20.7 & 20.7 & 100.0 & & & \\
\hline \multirow{3}{*}{$\begin{array}{l}\text { Observed } \\
\text { land use } \\
\text { changes } \\
\text { pattern in } \\
\text { Barotse } \\
\text { Floodplain }\end{array}$} & $\begin{array}{l}\text { Observed } \\
\text { changes }\end{array}$ & 218 & 80.7 & 80.7 & 80.7 & \multirow[t]{3}{*}{1.20} & \multirow[t]{3}{*}{.407} & \multirow[t]{3}{*}{270} \\
\hline & $\begin{array}{l}\text { Not observed } \\
\text { changes }\end{array}$ & 51 & 18.9 & 18.9 & 99.6 & & & \\
\hline & $\begin{array}{l}\text { Not } \\
\text { applicable }\end{array}$ & 1 & .4 & .4 & 100.0 & & & \\
\hline
\end{tabular}

Table 3 also shows that there is observed land use change pattern in BFP of about $80.7 \%$ as compared to other respondents (18.9\%) who claimed that they have not observed any change and only $0.4 \%$ was not aware of what has happened to the flood plain. The standard deviation for both driving forces of land use change and observed land use change pattern were found to be closer the mean and lower than 2 implying that there was normal distribution (see Table 3) according to principles of normal distribution.

The finding of this study therefore, agrees with Msofe (2019)'s findings that climate variability and extreme events such as prolonged dry spell and drought season affects wetlands and their ecosystems. Msofe (2019), also found out that increased market demands for cash crops such as rice, sesame and sugarcane coupled with improved road and rail infrastructure, policies that support investment in the wetlands resources, the advancement of agro-technology and increase in population led to land use change in the Kilombera valley flood plain in Tanzania. In our study we also found that climate variability, infrastructure development, demographic, technology and lastly agriculture leads to land use change in BFP.

Although agriculture was rated the least as a driver of land use change in the BFP due to non-existence of commercial agricultural activities it was observed to be playing a role in land use change. There are some subsistence and small-scale farmers who produce food (rice, maize and vegetables) mainly for household consumption and little surplus for sale and their field are constantly being expanded due to high demand for food and market. The scenario in BFP is the same as the one obtaining in Asia specifically in India where there is ever increasing loss of wetlands as a result of rice culture such that the gross areal extent of wetlands on the Indian subcontinent is probably greater today than it was 3000 years ago (Foote et al., 1996). Rice farming, a wetland- 
dependent activity, has been developed in virtually all suitable floodplains, riparian zones, river deltas and savannah areas in India. Noteworthy rice paddy conversion areas include DePar bil (Assam), Hokarsar Lake (Kashmir), and the Pyagpur and Sitadwar Jheels (very wet marshy areas) near Lucknow in Uttar Pradesh. Koleru Lake in Andhyra Pradesh has lost 34000 ha of natural wetlands to agriculture thus far (Anon. 1991).

Economic developments also affect land use in terms of growth in income and trust funds, rise in double-income households, changes in economic structure, agglomeration forces, global and local market development and organization of production process (Zondag and Borsboon, 2009). The high output market prices for agricultural products for example compel farmers to increase productivity through allocation of more resources such as labour, fertilizers and agro chemicals on limited land to maximize output hence agricultural intensification (Müller, 2004). The release of agricultural land (marginal or not) has been matched by socio-economic and policy context with unprecedented urbanization leading to the loss of ecological functions of land and soil (Ramsar, 2018). The economic driver also stimulates other infrastructure developments such as construction of roads, bridges and canals in the wetlands which leads to potential floods damages. In the BFP, high market output has led to expansion of rice fields hence stimulating land use change.

In the BFP, it was found that from 1990 to 2015 , there was precipitation variation. In some years there was excessive rainfall and scant rainfall in other years (Fig. 5 illustrates this) which affected hydrology in the wetland and consequently affecting its ecosystem functions. Zimba et al., (2018) found that there was downward inundation in the Barotse Flood plain, upper Zambezi River Basin due to climate change. Elsewhere, Zhang et al., (2017) argue that wetland ecosystems are particularly sensitive to climate variability as it affects hydrology, biogeochemical processes, plant communities and ecosystem functions. The temperature changes in Ebinur Lake Watershed, Western China led to high evaporation affecting the hydrology of the wetlands, although there was high precipitation timing in the area, the precipitation could not surpass the higher evaporation rate (Zhang et al., 2017). BFP is not an exemption to Zhang et al., (2017)'s findings since the area have the similar climatic condition of high temperature extremes of up to $40^{\circ} \mathrm{C}$ (Phiri et al., 2013). BFP has precipitation variation also as seen in Fig. 5.

The R squared value of 0.0831 on Fig. 3 indicates that there is a relationship between the rainfall amounts and climatic condition in various years. Fluctuating precipitation over the years in BFP were observed where the minimum was $571.7 \mathrm{~mm}$ in 2016 and maximum of $1579 \mathrm{~mm}$ in 2008 (see Fig. 5). This resulted into low flooding extent in some years posing a potential risk to the wetland hydrological functions. Wetlands play pivotal role in controlling floods by slowing down water movement, reducing water velocity and sedimentation (Keddy, 2000) and promoting aquifer replenishment (Bhatta et al., 2016; Gosselink and Turner, 1978).

The other land use changes that were observed in BFP were the construction of roads and bridges, settlements and mining of clay soil and sand for making bricks and blocks (see plate 3). In the northern part of the BFP, particularly in Lukulu, communities make bricks by the banks of Zambezi River (see Plate 2).

\section{Plate 2: Photo showing kiln of bricks by the banks of Zambezi River at Lukulu}

There is no monitoring and regulation done by authorities to advice the people not to be carrying out such activities in margins of the river and flood plain in the distances less than 10 meters from the river and such activities are intensified up stream). At Senanga, it was observed that a lagoon which was supposed to be the breeding site for fish has been drained and converted to a site for construction of a house/s (see Plate 3)

Page $13 / 24$ 
The construction of the road and bridge from Mongu to Kalabo also led to water not to move freely and flood the plain evenly due to embankment made for construction of the road (Plate 3). The road should have been built on elevated pillars across the plain from Mongu to Tapo so as to allow free movement of water in BFP and maintain the natural landscape of the plain. Phethi and Gumbo (2019) also found that in Makhitha wetland, Limpopo, Province, South Africa, a large area was used as a road in their study area as the road was constructed across the wetland so that local people could cross the wetland more easily without any inconvenience which is similar to what happened to the BFP where the road and bridge was constructed for the similar reason at the expense of the environment. Malekmohammadi and Blouchi (2014), argue that construction of such as roads and houses in wetlands is not a new activity as this has been practiced world over, leading to wetlands destruction and loss of biodiversity as it is a case in BFP.

\section{Plate 3: Photos showing different land uses in BFP}

The study further revealed that there was positive Pearson correlation coefficient of $0.266^{\star \star}$ between driving forces of land use change and observed land use changes pattern at observed p-value of 0.000 in BFP (See Table 4). Therefore, the correlation was highly significant at 0.01 level alluding that there are some factors that are causing land use change in BFP.

Table 4

Correlations between driving forces of land use change and observed land use changes pattern in BFP

\begin{tabular}{|c|c|c|c|}
\hline & & $\begin{array}{l}\text { Driving forces of land use } \\
\text { change in the Barotse } \\
\text { Floodplain }\end{array}$ & $\begin{array}{l}\text { Observed land use changes } \\
\text { pattern in Barotse } \\
\text { Floodplain }\end{array}$ \\
\hline \multirow{3}{*}{$\begin{array}{l}\text { Driving forces of land use } \\
\text { change in the Barotse } \\
\text { Floodplain }\end{array}$} & $\begin{array}{l}\text { Pearson } \\
\text { Correlation }\end{array}$ & 1 & $.266^{\star \star}$ \\
\hline & $\begin{array}{l}\text { Sig. }(2- \\
\text { tailed) }\end{array}$ & & .000 \\
\hline & $\mathrm{N}$ & 270 & 270 \\
\hline \multirow[t]{3}{*}{$\begin{array}{l}\text { Observed land use changes } \\
\text { pattern in Barotse Floodplain }\end{array}$} & $\begin{array}{l}\text { Pearson } \\
\text { Correlation }\end{array}$ & $.266^{\star \star}$ & 1 \\
\hline & $\begin{array}{l}\text { Sig. }(2- \\
\text { tailed) }\end{array}$ & .000 & \\
\hline & $\mathrm{N}$ & 270 & 270 \\
\hline
\end{tabular}

This therefore, follows that drivers of land use change have led to land use change as evidenced in detected land use change, observed land use activities and frequency statistics.

\subsection{Conclusion And Recommendation}

The study revealed that there is land use change in BFP caused by climate variability, infrastructure development, demographic, technology and agriculture. The study also found that there is significant correlation of $0.266^{\star *}$ between driving forces of land use change and observed land use changes pattern in BFP at 0.01 significance level (2-tailed). The Bayesian statistics revealed that posterior distribution was at 0.261 skewed to the right 
indicating that drivers of land use change has led to observed land use change in BFP. Climate variability was identified as leading driving force of land use change in the wetlands of BFP followed by infrastructure development and agriculture was the least. Climate variability has further led to precipitation variability over years which has consequently led to downward wetland inundation. The development of infrastructure such as roads was found not to be environmentally friendly as it was observed to be blocking the free movement of water in the flood plain a situation that has degraded the flood plain.

Since BFP is recognized and designated Ramsar heritage site, it should be protected and conserved by the Government of Zambia, Barotse Royal Establishment (Western Province traditional Leadership) and other stakeholders. Land and water management practices and use should influence the trade-offs between productivity and wetlands ecosystems protection in order to develop potential for land and water policies and governance that ensures conservation, poverty and vulnerability reduction as outlined in the Zambia's seventh national development plan (7NDP) and Sustainable Development Goals (SDGs) and help to minimize future wetlands degradation for survival of local people.

\section{Declarations}

\section{Author contributions}

A.M.B.: Conceptualization, Formal Analysis, Investigation, Methodology, Software, Data Curation, Writingoriginal draft, Visualization, Validation, K.B.: Project Administration, Supervision, Methodology, Validation, Writing - review \& editing. E.S: Methodology, Validation, Writing - review \& editing, M.C: Writing - review \& editing, I.A.N: Writing - review \& editing.

\section{Conflicts of interest}

There are no conflicts of interest to declare.

\section{Acknowledgements}

This work is supported with funding from WWF- Zambia through the Upper Zambezi Ecology and Ecology Project (Grant number 40001528). Special thanks to the communities that supported this work.

\section{References}

Alam, A, Rashid, S.M, Bhat, S. M and Sheikh, A. H (2011) Impact of land use/land cover dynamics on Himalayan wetland ecosystem, Journal of Experimental Sciences Vol. 2, Issue 3, pp 60-64

Alig, R. J, Darius M. A, and Bruce, M (1998) "Impacts of Incorporating Land Exchanges between Forestry and Agriculture in Sector Models." Journal of Agricultural and Applied Economics 30 (2): pp389-401

Anon (1991) World Resources 1991-1992. New York: Oxford University Press: pp 291

Aregheore E. 2009. Country Pasture/Forage Resources Profiles: Zambia. Rome: Food and Agriculture Organization of the United Nations

Page 15/24 
Banda, A, Sakala, E. N and Mulenga, M. C (2013) "Forest cover change and its effects on the dependent local people: The case of Sesheke District of Zambia." 'Journal of Baoji University of Arts and Sciences (Natural Science Edition), 5.

Banda, A. M (2017) Forest cover change and its effects on the dependent local communities in Masese Local Forest Reserve in Sesheke District. Dissertation, University of Zambia

Bhatta, D, L, Chaudhary, S, Pandit, A, Baral, H, Partha J. Das, P. J and Stork, N.E (2016) Ecosystem Service Changes and Livelihood Impacts in the Maguri-Motapung Wetlands of Assam, India, land:

https://www.researchgate.net/publication/303790517

Central Statistical Office (2012) 2010 Census of Population and Housing: Population Summary report, CSO, Lusaka

Cohen-Shacham, E, Dayan, T, de Groot, R, Beltrame, C, Guillet, F, Feitelson, E (2015) Using the ecosystem services concept to analyse stakeholder involvement in wetland management. Wetl. Ecol. Manag. 23, pp 241-256.

Davidson N (2014) How much wetland has the world lost? Long-term and recent trends in global wetland area. Marine and Freshwater Research 65: 934-941.DOI: 10.3390/land5020015

FAO (2008) FAO water reports: Scoping agriculture wetland interactions toward a sustainable multiple - response strategy, FAO, Rome

Finlayson, C.M and Davidson, N.C (2018) Global wetland outlook: Technical Nte on status and Trends, Gland, Switzerlands, Ramsar Convention Secretariat.

Flint L. 2006. Contradictions and challenges in representing the past: The Kuomboka Festival of Western Zambia. Journal of Southern African Studies 32(4):701-17.

Gardner, R. C., Barchiesi, S., Beltrame, C., Finlayson, C. M., Galewski, T., Harrison, I., Paganini, M., Perennou, C.,Pritchard, D. E, Rosenqvist, A., \& Walpole, M. (2015) State of the world's wetlands and their services to people: a compilation of recent analyses. Gland, Switzerland: Ramsar Briefing Note no. 7, Ramsar Convention Secretariat.

Geist, H. J and Lambin, E. F (2002). Proximate causes and underlying driving forces of tropical deforestation. BioScience 52, pp 143-150.

Gosselink, J.G, Turner, R.E (1978) The role of hydrology in freshwater ecosystems. In Freshwater Wetlands. Ecological Processes and Management Potential; Good, R.E., Whigham, D.F., Simpson, L.R., Eds.; Academic Press: New York, NY, USA; pp. 63-78.

Hagos, G., Temesgen,G. and Abraham, M (2014) Wetland degradation in Ethiopia causes consequences and remedies. Journal of Environmental Earth Science 4(11): 40 - 48.

Hulme PE (2005) Adapting to climate change: is there scope for ecological management in the face of a global threat? J Appl Ecol 42: 784-794

IPCC (2001) Climate Change 2001: Synthesis Report. A Contribution of Working Groups I, II, and III to the Third Assessment Report of the Intergovernmental Panel on Climate Change. R.T. Watson and Core Writing Team. 
Cambridge University Press, Cambridge, U.K. and New York, USA

IUCN (2003) Barotse Floodplain, Zambezi local economic dependence on wetland Resources; integrating wetland economic value into river basin management, The World Conservation Union Regional Office for Southern Africa, Harare

Journeaux, P, Van Reenen, E, Manjala,T, Pike, S, Hannore,I, Millar, S (2017) Analysis of drivers and Barriers to land use change: A report prepared for the Ministry for Primary industries in New Zealand

Keddy, P.A (2000) Wetland Ecology: Principles and Conservation; Cambridge University Press: Cambridge, UK

Keddy, P.A. Fraser, L.H. Solomeshch, A.I. Junk, W.J. Campbell, D.R. Arroyo, M.T.K. Alho, C.J.R (2009) Wet and wonderful: The world's largest wetlands are conservation priorities. Bioscience,59:39-51.

Lambin, E. F., Geist, H. J. and Lepers, E (2003) Dynamics of Land Use and Land Cover Change in Tropical Regions. Annual Review of Environment and Resources 28: 205-241

Mantyaka-Pringle, C, Leston, L, Messmer, D, Asong, E, Bayne, E.M, Bortolotti, L.E, Sekulic, G, Wheater, H, Howerter, D.W and Clark, R.G (2019) Antagonistic, synergistic and direct effects of land use and climate on Prairie wetland ecosystems: Ghosts of the past or present? John Wiley \& sons Ltd. Doi:10.1111/ddi.12990

Malekmohammadi, B. \& Blouci, L.R (2014) Écological risk assessment of wetland ecosystems using multi criteria decision making geographic information system', Ecological Indicators 41(1): 133-144.

https://doi.org/10.1016/j.ecolind.2014.01.038

McAllister, D.E. Craig, J.F. Davidson, N. Delany, S. Seddon, M (2001) Biodiversity Impacts of Large Dams; Background Paper No.1.; Prepared for IUCN/UNEP/WCD: Gland, Switzerland.

Millennium Ecosystem Assessment (MEA) (2005) Ecosystems and Human Well-being: Synthesis. Island Press, Washington DC. pp155

Mitsch, W.J and Gosselink, J.G (2007) Wetland, 4th ed.; Wiley: New York, NY, USA.

Mitsch, W.J and Gosselink, J.G (2000) The value of wetlands: Importance of scale and landscape setting. Ecol. Econ.,35: 25-33.

Müller, D (2004) From agricultural expansion to intensification: Rural development and determinants of landuse change in the Central Highlands of Vietnam, in Tropical Ecology Support Programme (TOEB) Report, Deutsche Gesellschaft für: Eschborn.

Msofe, N.K (2019) Socio-Ecological Drivers of Land Use Change and Wetland Conversion in Kilombero Valley Floodoplain, Tanzania. American Journal of Environmental and Resource Economics. Vol. 4, No. 1, pp. 1-11. doi:10.11648/j.ajere.20190401.11

Nguyen, H. H, Dargusch, P, Patrick, M and Ammar A. A (2017) Land-use change and socio-ecological drivers of wetland conversion in Ha Tien Plain, Mekong Delta, Vietnam. Land Use Policy 64: 101-113. 
Phethi, M.D \& Gumbo, J.R (2019) 'Assessment of impact of land use change on the wetland in Makhitha village, Limpopo province, South Africa', Jàmbá: Journal of Disaster Risk Studies 11(2), a693. https://doi.org/ 10.4102/jamba.v11i2.69

Phiri, J. S, Moonga, E, Mwangase,O Chipeta, G (2013) Adaptation of Zambian Agriculture To Climate Change- A Comprehensive Review of the Utilisation of The Agro-Ecological Regions; Climate Change, Agriculture and AgroEco Regions of Zambia, A Review for Policy Makers. Zambia Academy of Sciences (ZaAS), Lusaka

Piggott, J. J., Townsend, C. R., \& Matthaei, C. D (2015) Climate warming and agricultural stressors interact to determine stream macroinvertebrate community dynamics. Global Change Biology, 21: 1887-1906. https://doi.org/10.1111/gcb.12861

Redman, C. L., Grove, J. M and Kuby, L. H (2004) Integrating Social Science into the Long-Term Ecological Research (LTER) Network: Social Dimensions of Ecological Change and Ecological Dimensions of Social Change. Ecosystems 7(2): 161-171

Ramsar Convention on Wetlands (1971) "Wetlands and water: supporting life, sustaining livelihoods" Resolution IX.1 Annex C ii Guidelines for the management of groundwater to maintain wetland ecological character, Kampala, Uganda, 8-15 November 2005

Ramsar Convention on Wetlands (2018) Global Wetland Outlook: State of the World's Wetlands and their Services to People. Gland, Switzerland: Ramsar Convention Secretariat

Ramsar Convention Secretariat (RCS) (2007) Wise use of wetlands: A conceptual framework for the wise use of wetlands. In Ramsar Handbooks for the Wise Use of Wetlands, 3rd ed.; RCS: Gland, Switzerland; pp. 8-9.

Rebelo, L.M. McCartney, M.P. Finlayson, C.M (2009) Wetlands of sub-Saharan Africa: Distribution and contribution of agriculture to livelihoods. Wetl. Ecol. Manag. 18 pp 557-555.

Ricaurte, L.F. Wantzen, K.M. Agudelo, E. Betancourt, B. Jokela, J (2014) Participatory rural appraisal of ecosystem services of wetlands in the Amazonian Piedmont of Colombia: Elements for a sustainable management concept. Wetl. Ecol. Manag. 22: 343-361.

Schuyt, K. 2005. Economic consequences of wetland degradation for local populations in Africa. Ecol. Econ.

Shand, P, Grocke,S, Creeper,N.L, Baker,A.K, Fitzpatrick,R.W and Love, A.J (2017) Impacts of climate change, climate variability and management on soil and water quality in wetlands of South Australia; Elsevier, Procedia Earth and Planetary Science 17: 456 - 459

Stavins, R. N and Adam, B (1990) “Unintended Impacts of Public Investments on Private Decisions: The Depletion of Forested Wetlands." American Economic Review 80 (3): 337-52

Taniwaki, R. H, Piggott, J. J, Ferraz, S. F, \& Matthaei, C. D (2017) Climate change and multiple stressors in small tropical streams. Hydrobiologia, 793: 41-53. https://doi.org/10.1007/s10750-016-2907-3

Timberlake, J (2000) Biodiversity of the Zambezi Basin, vol. 09. Biodiversity Foundation for Africa, pp. 1-20.

Veldamp, A and Lambin, E. F (2000) Predicting land use change, Agriculture, Ecosystem and Environment, 85: 1-6 
Wei, Q. Tong, L. Gondwe, J. Lv, X. Tong, W. Liu, Y (2015) Non-use value trends analysis of wetland ecosystem in the Sanjiang Plain, Northeast China. Wetl. Ecol. Manag. 23: 347-355.

Zhang, F., Kung, H. and Johnson, V (2017) Assessment of Land-Cover/Land-Use Change and Landscape Patterns in the Two National Nature Reserves of Ebinur Lake Watershed, Xinjiang, China. Sustainability 9(5): pp 724.

Zimba, H, Banda, K, Chabala, A, Phiri, W, Selsman, P, Meinhardi, M, Nyanbe, I (2018) Asssessment trends in inundation extent in the Barotse Flood plain, upper Zambezi River Basin: A remote sensing approach. Journal of Hydrology: Regional Studies, Elsevier.www.com/locate/ejrh

Zondag, B and Borsboon, J (2009) Driving force of land-use change: Paper prepared for the $49^{\text {th }}$ ERSA Conference August 2009, Lodzi, Poland

\section{Figures}

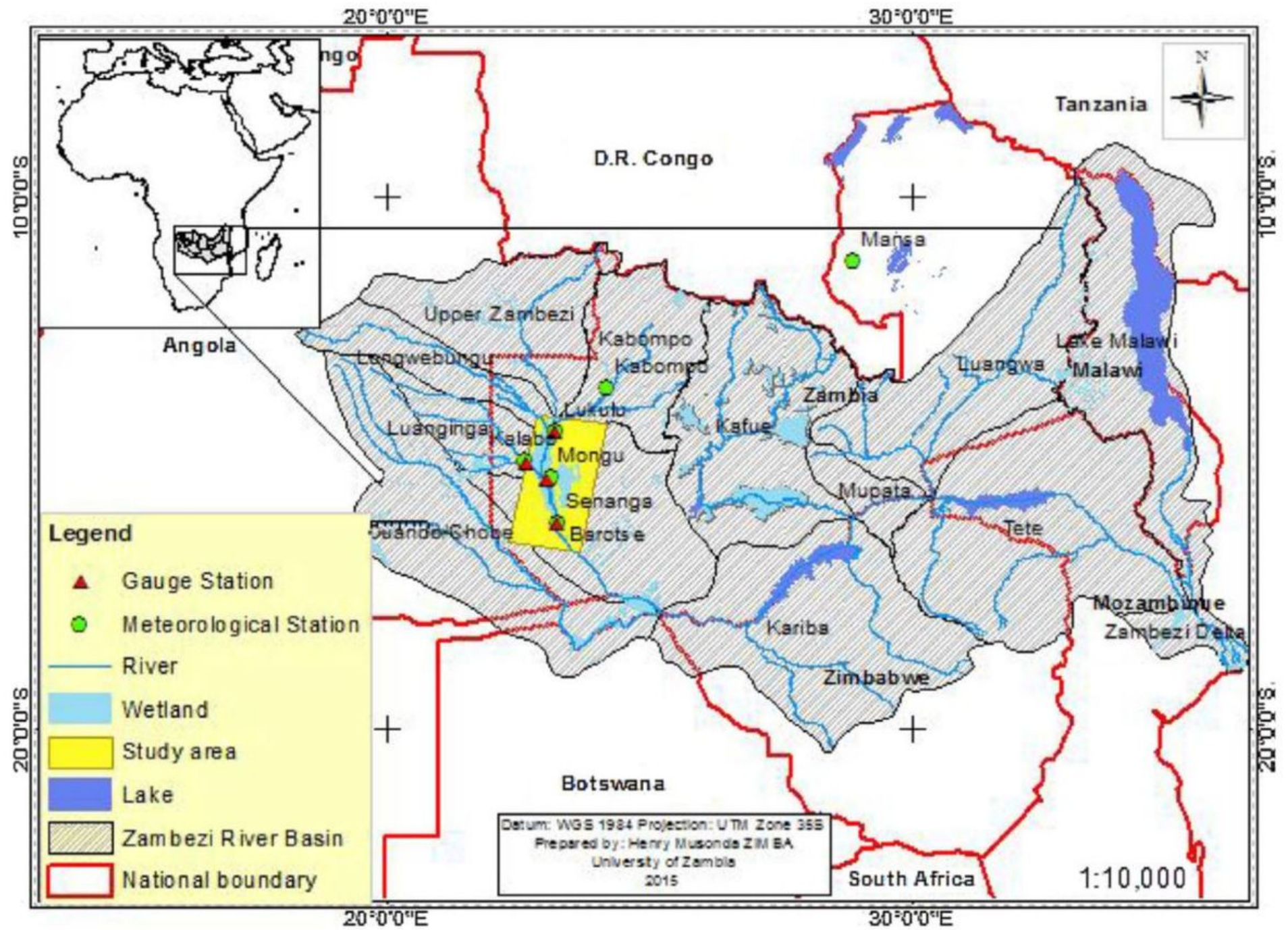

Figure 1

Map showing Barotse Floodplain in Western Province, Zambia (Adapted from Zimba, 2017) 
Land Use change and its Drivers in the Wetlands of Barotse Floodplain of Zambezi River Sub-Basin, Zambia
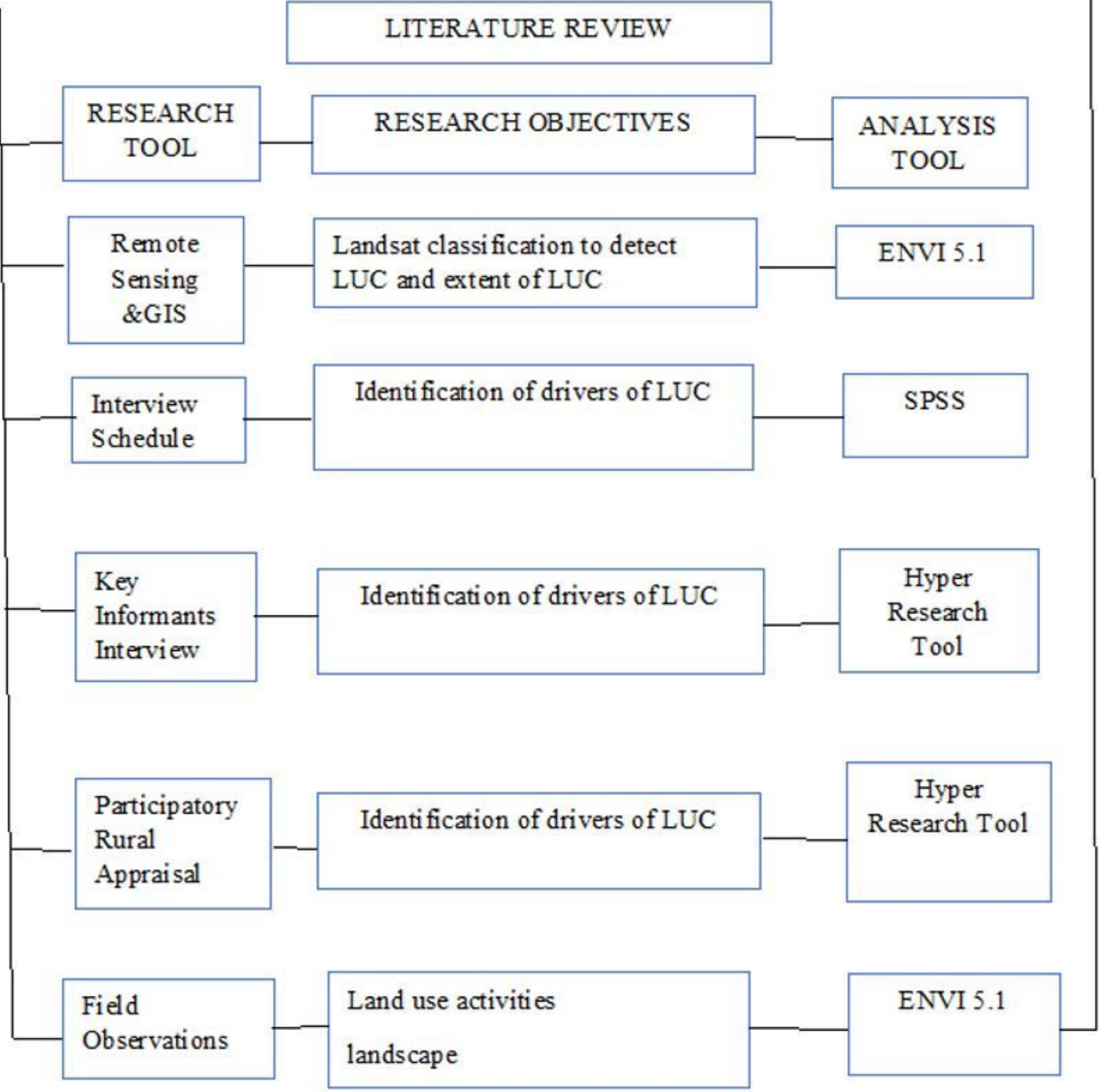

Figure 2

Integrated research model/approach 


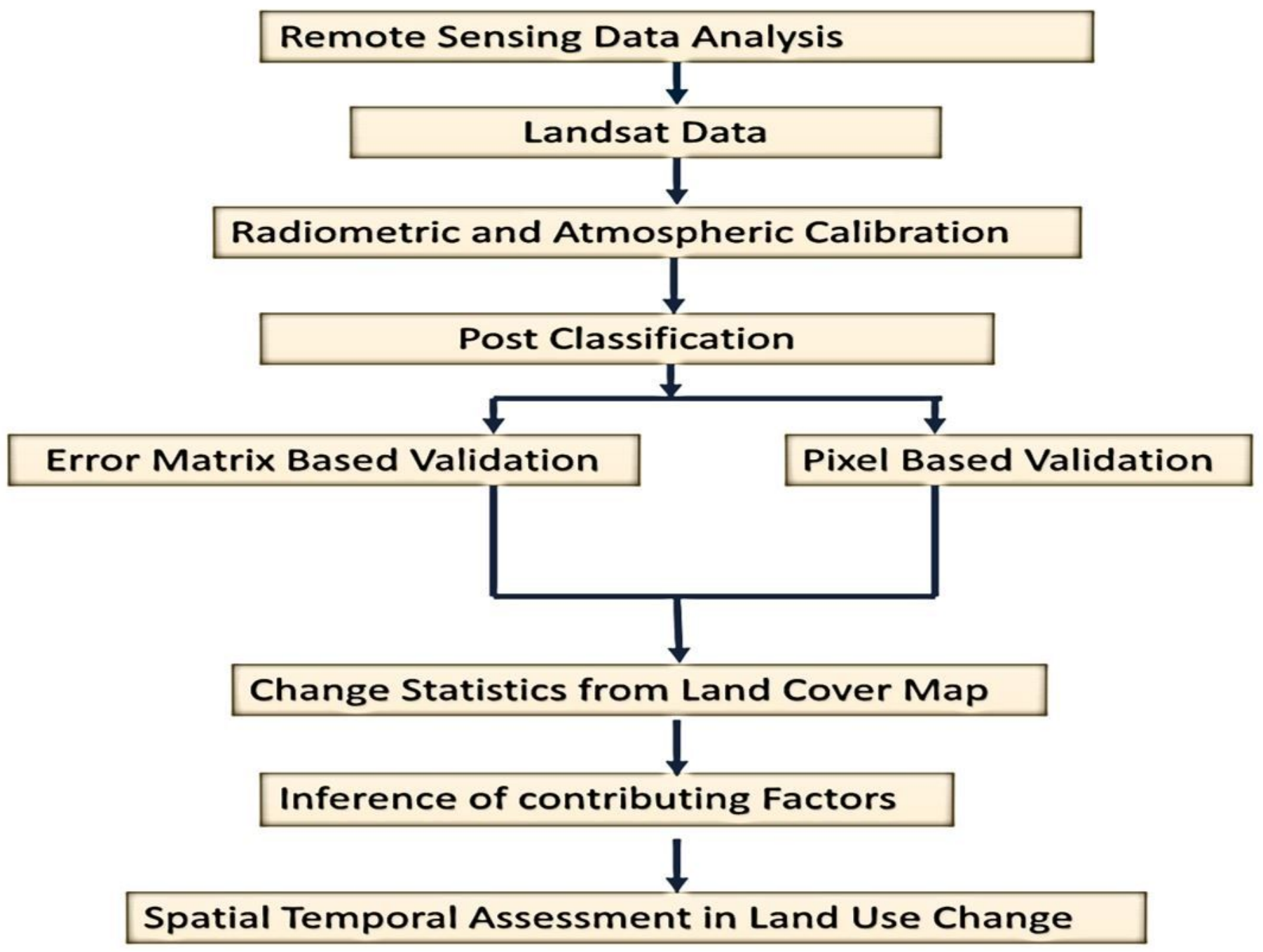

Figure 3

Study approach to analyse of land use change in BFP. 


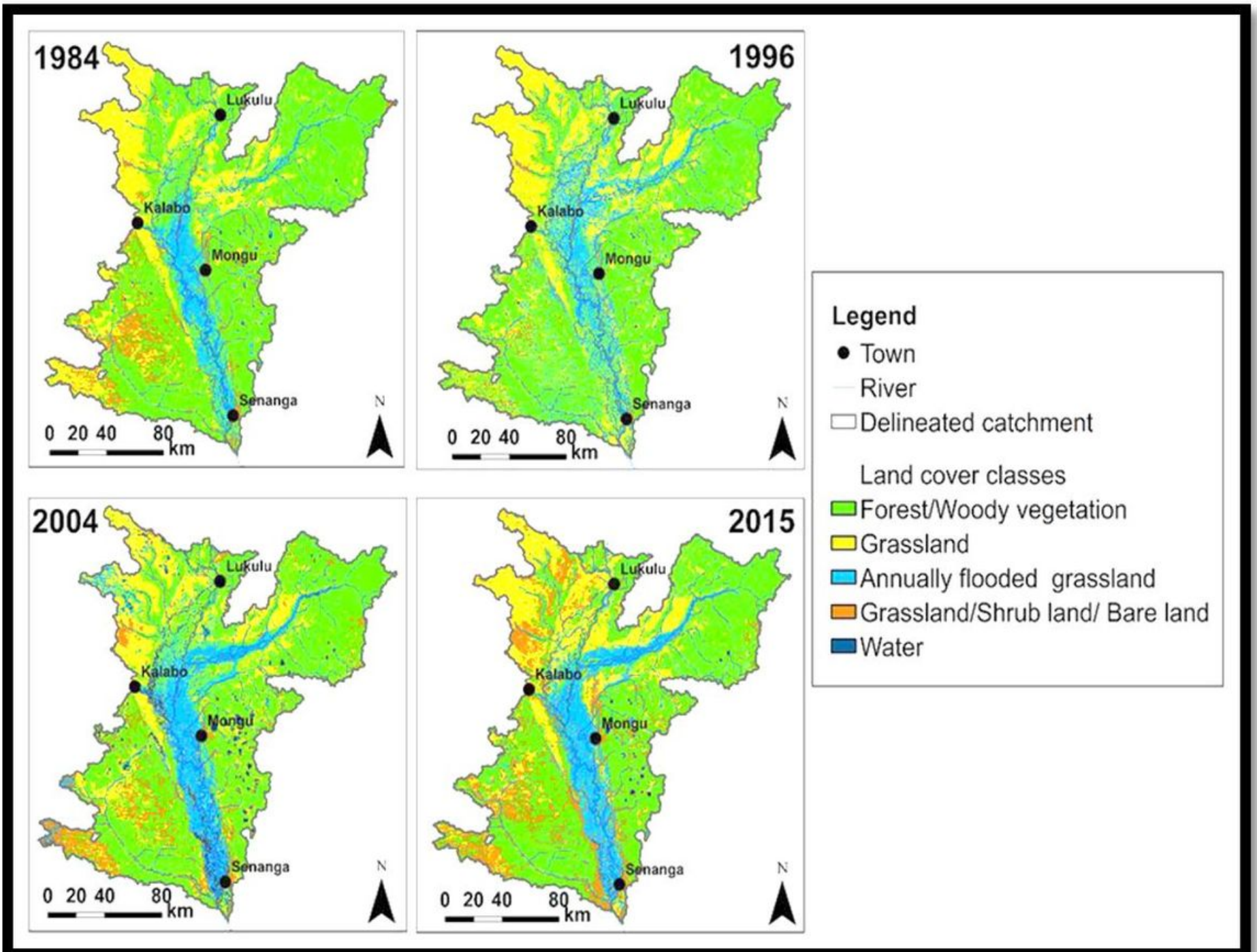

Figure 4

Land cover classification for the years 1984, 1996, 2004 and 2015 in the BFP (Adapted from Zimba, 2017) Note: The designations employed and the presentation of the material on this map do not imply the expression of any opinion whatsoever on the part of Research Square concerning the legal status of any country, territory, city or area or of its authorities, or concerning the delimitation of its frontiers or boundaries. This map has been provided by the authors. 


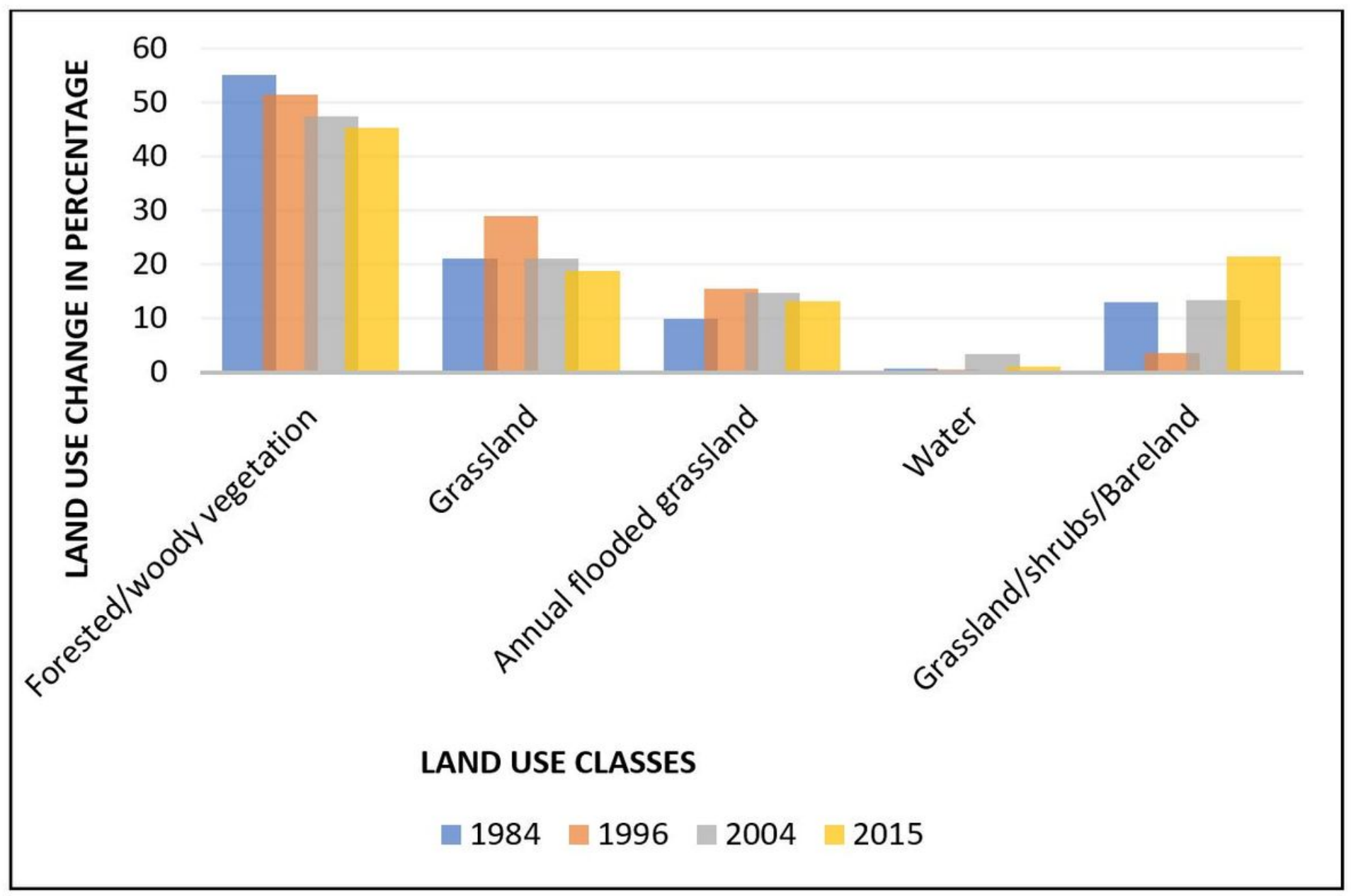

Figure 5

Bar chart showing land use changes in percentage in years (1984,1996, 2004 and 2015) 


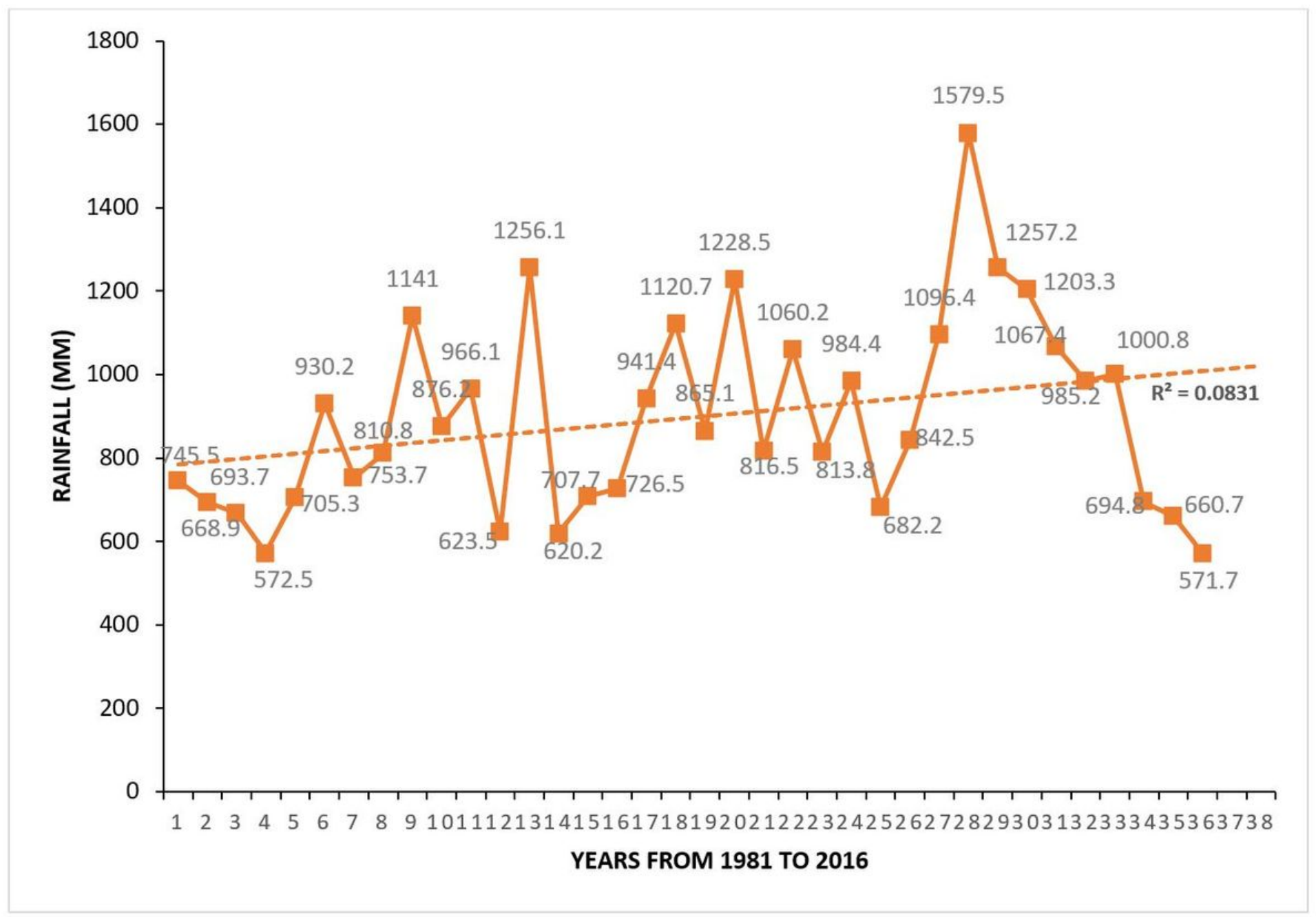

Figure 6

Graph showing annual rainfall variation from 1981 to 2016 in BFP, Mongu (Source: Zambia Meteorology Department)

\section{Supplementary Files}

This is a list of supplementary files associated with this preprint. Click to download.

- plate1.jpg

- plate2.jpg

- plate3.jpg 